\title{
High mortality in obese women diabetics with acute myocardial infarction
}

\author{
M J B TANSEY, L H OPIE, B M KENNELLY
}

British Medical fournal, 1977, 1, 1624-1626

\begin{abstract}
Summary
The factors associated with mortality in 89 diabetics and 793 non-diabetics with acute myocardial infarction who were initially admitted to a coronary care unit were analysed retrospectively. During their stay in hospital diabetics had twice the mortality of non-diabetics. The higher mortality among diabetics was largely accounted for by obese women, who had a hospital mortality of $43 \%$. There was an increased incidence of congestive heart failure in such patients. A therapeutic trial should be performed in such patients to assess whether insulin has an effect on infarct size.
\end{abstract}

\section{Introduction}

Almost without exception studies have shown a very high mortality rate in diabetics with acute myocardial infarction..$^{1-5}$ We have found a clinical association between a high mortality rate and obesity in women diabetics with acute myocardial infarction, and we therefore undertook a retrospective analysis of deaths among diabetics with myocardial infarction with special reference to the role of obesity.

\section{Patients and methods}

The records of 882 consecutive patients admitted to the coronary care unit with proved myocardial infarction from January 1972 to December 1974 were reviewed. Eighty-nine $(10 \%)$ of these patients were diabetic. The age distribution in diabetic and non-diabetic patients was the same. Patients were not admitted to the coronary care unit if more than 72 hours had elapsed since the onset of symptoms unless late complications had developed. Otherwise admission to the unit was restricted only by the availability of beds and by age: patients aged over 70 years with suspected acute myocardial infarction but without complications were not routinely admitted to the unit but to the general wards.

Acute myocardial infarction was defined by the presence of at least two of the following features: $(a)$ a history of prolonged chest pain suggestive of acute myocardial infarction; $(b)$ new $Q$ waves or typical evolutionary ischaemic ST-T wave changes on the electrocardiogram; (c) a characteristic rise and fall in the levels of the serum enzymes, creatine phosphokinase, aspartate transaminase, and lactic dehydrogenase. In the 89 diabetic patients diabetes had been diagnosed and treatment started before admission. Obesity was defined subjectively by the admitting doctor, who had to make an appropriate entry on a computer form, and actual weights and skinfold thickness measurements were therefore not available. Hypotension was defined as a systolic blood pressure of less than $90 \mathrm{~mm} \mathrm{Hg}$ and shock by the presence of two or more of the following findings: $(a)$ systolic blood pressure of $90 \mathrm{~mm} \mathrm{Hg}$ or less for 30 minutes or more; $(b)$ urine flow

Cardiac Clinic, Groote Schuur Hospital, Observatory, South Africa $M$ J B TANSEY, BSC, $M B$, research registrar

B M KENNELLY, PHD, MRCP, senior lecturer and principle specialist physician

Medical Research Council Ischaemic Heart Disease Unit, University of Cape Town, South Africa

L H OPIE, MD, FRCP, associate professor of medicine, director of unit of less than $30 \mathrm{ml} / \mathrm{h}$ despite a fluid intake of over $100 \mathrm{ml} / \mathrm{h} ;(c)$ evidence of reduced organ perfusion, as shown by cold cyanosed peripheries or mental confusion.

Statistical significance was calculated by the $\% "$ test, and $P$ values of over 0.05 were not regarded as significant. The term mortality refers to the death rate up to the time of discharge from hospital.

All data on the patients' stay in the coronary care unit and the dates of and causes of death in hospital after leaving the unit were stored and retrieved by computer. Information on the duration of diabetes, the type of treatment, and its effectiveness before admission was obtained from the hospital records, which were available for 81 of the 89 patients.

\section{Results}

Ten per cent of patients arrived in the coronary care unit within two hours, $40 \%$ within six hours, $67 \%$ within 12 hours, and $95 \%$ within 24 hours. The delay was not significantly different in diabetics and non-diabetics. Both groups stayed the same length of time in the unit (median four days). The mortality in the coronary care unit was $20 \%$ for diabetics (18 deaths) and $9 \%$ for non-diabetics (72 deaths) $(\mathrm{P}<0.001)$, while in the wards the mortality was $8 \%(7$ deaths $)$ and $5 \%$ (38 deaths) respectively. Shock or congestive cardiac failure, or both, was the major cause of death in both diabetics $(52 \%)$ and nondiabetics $(65 \%)$, followed by primary arrhythmias $(28 \%$ and $27 \%$ respectively). There was no significant difference in cause of death between the two groups.

The hospital mortality in diabetics and non-diabetics is shown in table I. The overall mortality was $15 \%$, but the mortality in diabetics was higher than that in non-diabetics. Mortality was higher among female diabetics than among male diabetics $(\mathbf{P}<0.05)$ or female non-diabetics $(P<0.01)$

Table II lists some associated conditions that have prognostic significance in acute myocardial infarction. ${ }^{36-8}$ The incidences of hypertension, obesity, and congestive cardiac failure were significantly higher among diabetics than among non-diabetics; and the mortality associated with hypertension, angina, angina of more than one month's duration, and an anterior site of infarct was higher in diabetics than non-diabetics. Because of the high mortality associated with obesity in diabetic women this group was studied in more detail. Mortality in obese diabetic women $(43 \%)$ was eight times that in obese diabetic men $(5 \%)(P<0.01)$, twice that in all other diabetics $(20 \%)(P<0.05)$, and three times that in non-diabetics $(14 \%)(\mathbf{P}<0.001)$. The incidence of the adverse prognostic factors and the associated mortality in this group of women was no different from that in all other diabetics. But obese female diabetics did have a higher incidence of congestive cardiac failure than all other diabetics $(P<0 \cdot 05)$ and non-diabetics $(P<0 \cdot 001)$. Mean age, place of death (coronary care unit or general ward), time of death after admission, and causes of death were the same for obese female diabetics as for all other diabetics.

The mortality among obese female diabetics and all other diabetics was considered in relation to the type of treatment: diet alone, oral agents, or insulin (table III). Obese female diabetics treated with diet alone had a higher mortality than all other diabetics $(P<0.02)$, but there were no other significant differences.

\section{Discussion}

Although obesity is an equivocal risk factor in the genesis of coronary artery disease, ${ }^{9}$ its influence on the prognosis for diabetics with acute myocardial infarction deserves closer consideration. Obesity and diabetes may have several abnormalities in common, such as an abnormal carbohydrate metabolism, ${ }^{1011}$ increased insulin resistance, ${ }^{11-13}$ a high fasting concentration of free fatty acids in the blood, ${ }^{14-16}$ and a high incidence of hypertension. ${ }^{917}$ The existence of these abnormalities 
TABLE I-Hospital mortality in 89 diabetics and 793 non-diabetics according to sex

\begin{tabular}{|c|c|c|c|c|c|c|}
\hline & \multicolumn{2}{|c|}{ Overall } & \multicolumn{2}{|c|}{ Men } & \multicolumn{2}{|c|}{ Women* } \\
\hline & $\begin{array}{c}\text { No of } \\
\text { admissions }\end{array}$ & $\begin{array}{l}\left.\text { No (" }{ }^{\circ}\right) \\
\text { of deaths }\end{array}$ & $\begin{array}{c}\text { No of } \\
\text { admissions }\end{array}$ & $\begin{array}{l}\text { No (") } \\
\text { of deaths }\end{array}$ & $\begin{array}{c}\text { No of } \\
\text { admissions }\end{array}$ & $\begin{array}{l}\text { No }\left({ }^{\circ}, 0\right) \\
\text { of deaths }\end{array}$ \\
\hline $\begin{array}{l}\text { Diabetic } \\
\text { Non-diabetic }\end{array}$ & $\begin{array}{r}89 \\
793\end{array}$ & $\begin{array}{r}25(28) \\
110(14)\end{array}$ & $\begin{array}{r}49 \\
623\end{array}$ & $\begin{array}{r}9(18) \\
76(12)\end{array}$ & $\begin{array}{r}40 \\
170\end{array}$ & $\begin{array}{l}16(40) \\
34(20)\end{array}$ \\
\hline$P$ value & & $<0.001$ & & NS & & $<0.01$ \\
\hline
\end{tabular}

"There were significantly more women among the diabetics than among the non-diabetics $(P<0.001)$.

NS $=$ Not Significant

TABLE II-Incidence of and mortality associated with certain potentially adverse prognostic factors in 89 diabetics and 793 non-diabetics with acute myocardial infarction

\begin{tabular}{|c|c|c|c|c|c|c|}
\hline & \multicolumn{2}{|c|}{ Diabetics } & \multicolumn{2}{|c|}{ Non-diabetics } & \multirow[b]{2}{*}{$\begin{array}{l}P \text { value } \\
A v C\end{array}$} & \multirow[b]{2}{*}{$\begin{array}{l}\mathrm{P} \text { value } \\
\mathrm{B} v \mathrm{D}\end{array}$} \\
\hline & $\begin{array}{c}\text { No }\left(" .,{ }^{\prime}\right) \text { of patients } \\
\text { at risk } \\
(A)\end{array}$ & $\begin{array}{l}\text { No ("..) of deaths } \\
\text { (B) }\end{array}$ & $\begin{array}{l}\text { No (").) of patients } \\
\text { at risk } \\
\text { (C) }\end{array}$ & $\begin{array}{l}\text { No (".") of deaths } \\
\text { (D) }\end{array}$ & & \\
\hline Total No of patients & $89(10)$ & $25(28)$ & $793(90)$ & $110(14)$ & & $<0.001$ \\
\hline \multicolumn{7}{|c|}{ Factors present before infarction } \\
\hline $\begin{array}{l}\text { Hypertension } \\
\text { Previous infarction } \\
\text { Angina of }>1 \text { month's duration }\end{array}$ & $\begin{array}{l}38(43) \\
22(25) \\
28(31)\end{array}$ & $\begin{array}{r}12(32) \\
6(27) \\
11(39)\end{array}$ & $\begin{array}{l}188(24) \\
198(25) \\
297(37)\end{array}$ & $\begin{array}{l}27(14) \\
37(19) \\
44(15)\end{array}$ & $\begin{array}{l}<0.001 \\
\text { NS } \\
\text { NS }\end{array}$ & $\begin{array}{l}<0.02 \\
\text { NS } \\
<0.001\end{array}$ \\
\hline $\begin{array}{l}\text { Obesity: } \\
\text { Overall } \\
\text { Men } \\
\text { Women } \\
\text { Cardiomegaly on admission }\end{array}$ & $\begin{array}{l}50(56) \\
20(22) \\
30(34) \\
24(27)\end{array}$ & $\begin{aligned} 14(28) \\
1(5) \\
13(43) \\
11(46)\end{aligned}$ & $\begin{array}{r}236(30) \\
158(20) \\
78(10) \\
184(23)\end{array}$ & $\begin{array}{l}26(11) \\
16(10) \\
10(13) \\
55(30)\end{array}$ & $\begin{array}{l}<0.001 \\
\text { NS } \\
<0.001 \\
\text { NS }\end{array}$ & $\begin{array}{l}<0.01 \\
\text { NS } \\
<0 \cdot 001 \\
\text { NS }\end{array}$ \\
\hline \multicolumn{7}{|c|}{ Factors arising after infurction } \\
\hline $\begin{array}{l}\text { Congestive cardiac failure } \\
\text { Hypotension on admission } \\
\text { Shock } \\
\text { Anterior site of infarct } \\
\text { Primary ventricular fibrillation }\end{array}$ & $\begin{array}{c}40(45) \\
6(7) \\
11(12) \\
24(27) \\
4(4)\end{array}$ & $\begin{aligned} & 17(43) \\
& 6(100) \\
& 11(100) \\
& 13(54) \\
& 4(100)\end{aligned}$ & $\begin{array}{c}213(27) \\
43(5) \\
58(7) \\
367(46) \\
22(3)\end{array}$ & $\begin{array}{l}73(34) \\
29(67) \\
53(91) \\
58(16) \\
17(77)\end{array}$ & $\begin{array}{l}<0 \cdot 001 \\
\text { NS } \\
\text { NS } \\
\text { NS } \\
\text { NS }\end{array}$ & $\begin{array}{l}\text { NS } \\
\text { NS } \\
\text { NS } \\
<0 \cdot 02 \\
\text { NS }\end{array}$ \\
\hline
\end{tabular}

TABLE III-Mortality according to type of diabetic treatment in obese female diabetics and all other diabetics

\begin{tabular}{|c|c|c|c|c|c|}
\hline & \multicolumn{2}{|c|}{ Obese female diabetics } & \multicolumn{2}{|c|}{ All other diabetics* } & \multirow{2}{*}{$\begin{array}{l}\text { Significance of difference } \\
\text { in mortality } \\
\text { ( } P \text { value) }\end{array}$} \\
\hline & $\begin{array}{l}\text { No of patients per } \\
\text { treatment group }\end{array}$ & No $(" .$,$) of deaths$ & $\begin{array}{l}\text { No of patients per } \\
\text { treatment group }\end{array}$ & No ("v) of deaths & \\
\hline $\begin{array}{l}\text { Diet } \\
\text { Oral agents } \\
\text { Insulin }\end{array}$ & $\begin{array}{r}7 \\
20 \\
3\end{array}$ & $\begin{array}{l}5(71) \\
6(30) \\
2(67)\end{array}$ & $\begin{array}{r}17 \\
29 \\
5\end{array}$ & $\begin{array}{l}1(6) \\
8(28) \\
3(60)\end{array}$ & $\begin{array}{l}<0.02 \\
\text { NS } \\
\text { NS }\end{array}$ \\
\hline Total & 30 & $13(43)$ & 51 & $12(24)$ & NS \\
\hline
\end{tabular}

*Only 51 of the remaining 59 diabetics were included in this analysis, but all patients who died were included.

may worsen the prognosis in acute myocardial infarction, ${ }^{18-20}$ which may explain the adverse effects of obesity combined with diabetes.

In our series the mortality in obese and in non-obese diabetics was identical $\left(28^{\circ}{ }^{\circ}\right)$, but obese women diabetics had a hospital mortality eight times that of obese men diabetics, twice that of all other diabetics, and three times that of non-diabetics. When obese women were excluded the remaining diabetics did not have a significantly higher mortality than non-diabetics. Other studies have not shown that obesity influences mortality in diabetics with acute myocardial infarction, ${ }^{21-24}$ but all these studies were performed before coronary care units were established. Since the introduction of coronary care units overall mortality from acute myocardial infarction has fallen significantly, though diabetics have not benefited to the same extent as non-diabetics. ${ }^{25}$

The reason for the higher mortality associated with infarction only in women diabetics is not clear. Diabetic women are more susceptible to infarction than non-diabetic women, ${ }^{4224}$ and the incidence of obesity in women diabetics is higher than that in men diabetics or non-diabetics. ${ }^{26}$ The increased incidence of congestive cardiac failure suggests that obese women diabetics may have larger infarcts.

Among diabetics treated with diet alone obese women had a significantly higher mortality than all other diabetics $(P<0.02)$, whereas there were no differences in the groups treated with oral agents or insulin. Non-obese diabetics treated with diet had a lower mortality than those treated with oral agents or insulin, which suggests that in obese women diabetics under the stress of myocardial infarction treatment with diet alone is insufficient. Treatment of all obese diabetics with insulin after acute myocardial infarction may bring benefit by improving the metabolic function of the myocardium, which may be impaired by the combined effects of ischaemia, diabetes, ${ }^{25} 27$ and obesity.

Identification of this high-risk group of obese diabetics raises several issues that need further study. Among these is the question of how treatment can be improved. Stricter control of body weight from the time that diabetes is diagnosed might reduce the problem considerably. Prolonging the stay of diabetic patients in a coronary care unit should not reduce mortality any more than in non-diabetics, since mortality rates after discharge from the coronary care unit were similar in diabetic and nondiabetic patients. Studies might profitably be carried out to determine whether obese women diabetics have larger infarcts than other patients and whether the use of insulin and measures aimed at reducing infarct size would result in reduced morbidity and mortality.

We thank the medical superintendent of Groote Schuur Hospital for permission to report these findings and the programmers of the Provincial Service for computer analyses of records. Thanks are also due to Miss M Kavalsky for secretarial help. 
Requests for reprints should be addressed to: Dr M J B Tansey, Cardiac Clinic, Groote Schuur Hospital, Observatory, Cape 7900 South Africa.

\author{
References \\ ${ }^{1}$ McGuire, L B, and Kroll, M S, Archives of Internal Medicine, 1972, 130, \\ 677. \\ 2 Soler, N G, et al, Lancet, 1974, 1, 475. \\ ${ }^{3}$ Henning, R, and Lundman, T, Acta Medica Scandinavica, 1975, suppl \\ No 586 . \\ 4 Harrower, A D B, and Clarke, B F, British Medical fournal, 1976, 1, 126. \\ - Lichstein, E, et al, American fournal of Cardiology, 1976, 38, 100. \\ ${ }^{6}$ Hughes, W L, et al, Archives of Internal Medicine, 1963, 111, 338. \\ ${ }^{7}$ Norris, R M, et al, Lancet, 1969, 1, 274. \\ ${ }^{8}$ Helmers, C, Acta Medica Scandinavica, 1974, suppl No 555. \\ - Stamler, J, Medical Clinics of North America, 1973, 57, 5. \\ ${ }^{10}$ Ford, S R, Bozain, R C, and Knowles, H C, jun, American fournal of \\ Clinical Nutrition, 1968, 21, 904. \\ 11 Felig, P, Medical Clinics of North America, 1971, 55, 821 \\ ${ }^{12}$ Fraser, R, et al, Journal of Endocrinology, 1962, 25, 299. \\ ${ }^{13}$ Kreisberg, R A, et al, New England fournal of Medicine, 1967, 276, 314.
}

${ }^{14}$ Opie, L H, and Walfish, P G, New England Fournal of Medicine, 1963, 268, 757.

15 Reitsma, W D, Acta Medica Scandinavica, 1967, 182, 353.

${ }^{16}$ Reinheimer, W, et al, American fournal of Clinical Nutrition, 1967, 20, 986.

17 Pell, S, and D'Alonzo, C A, fournal of the American Medical Association, 1967, 202, 104.

18 Opie, L H, American fournal of Cardiology, 1975, 36, 938.

19 Peel, A A F, et al, British Heart fournal, 1962, 24, 745.

20 Pell, S, and D'Alonzo, C A, New England fournal of Medicine, 1964, 270, 915.

${ }^{21}$ Robinson, J W, New England fournal of Medicine, 1952, 246, 332.

${ }^{22}$ Bradley, R F, and Bryfogle, J W, American fournal of Medicine, 1956, 20, 207.

${ }^{23}$ Jarrett, R J, Postgraduate Medical fournal, 1961, 37, 207.

${ }^{24}$ Partamian, J O, and Bradley, R F, New England fournal of Medicine, 1965 , 273, 455.

${ }^{25}$ Opie, L H, Tansey, M J B, and Kennelly, B M, in Modern Topics in Diabetes Mellitus, ed T D R Hockaday and K G M Alberti. London, Heinemann. In press.

${ }^{26}$ Jackson, W P U, On Diabetes Mellitus. Springfield, Illinois, Charles C Thomas, 1964.

${ }^{27}$ Hearse, D J, Stewart, D A, and Chain, E B, fournal of Molecular and Cellular Cardiology, 1975, 7, 397.

(Accepted 14 April 1977)

\title{
Sequential treatment with quinine and mefloquine or quinine and pyrimethamine-sulfadoxine for falciparum malaria
}

\author{
ANTHONY P HALL, EDWARD B DOBERSTYN, CHUL KARNCHANACHETANEE, \\ SAMRAN SAMRANSAMRUAJKIT, BANHARN LAIXUTHAI, ELIOT J PEARLMAN, \\ RICHARD M LAMPE, CHARLES F MILLER, PUNG PHINTUYOTHIN
}

British Medical fournal, 1977, 1, 1626-1628

\section{Summary}

Patients with falciparum malaria were studied in Thailand, an area of known chloroquine resistance. The patients were unselected and some had severe malaria, and they were randomly assigned to one of two sequential regimens. A short course of quinine (average 4 doses, equivalent to $2 \mathrm{~g}$ base) followed by a single dose of pyrimethamine-sulfadoxine (Fansidar) cured $92 \%$ of patients (36 out of 39 ), while a short course of quinine followed by a single $1 \cdot 5-\mathrm{g}$ dose of mefloquine cured all of the 35 patients who could be followed up. Gastrointestinal side effects were minimal if at least 12 hours elapsed between the last dose of quinine and the mefloquine.

Sequential quinine and mefloquine is the most effective treatment for patients with chloroquine-resistant falciparum malaria, including those with severe or complicated disease. Mefloquine, however, is not com-

SEATO Medical Research Laboratory, Bangkok, Thailand

ANTHONY P HALL, FACP, chief, department of medicine (present address: Hospital for Tropical Diseases, London NW1 OPE)

EDWARD B DOBERSTYN, MD, physician

BANHARN LAIXUTHAI, MD, physician

ELIOT J PEARLMAN, MD, chief, department of epidemiology

RICHARD M LAMPE, $M D$, physician

CHARLES F MILLER, MD, physician

PUNG PHINTUYOTHIN, MD, physician

Prachinburi Provincial Hospital, Thailand

CHUL KARNCHANACHETANEE, MD, physician

SAMRAN SAMRANSAMRUAJKIT, MD, hospital director mercially available, and the similar regimen using Fansidar is almost as effective.

\section{Introduction}

Falciparum malaria in Thailand is usually resistant to chloroquine. ${ }^{1-3}$ We have recently shown that the most effective treatment for chloroquine-resistant falciparum malaria consists of a short course of quinine (about four doses) followed by a single dose of sulfadoxine-pyrimethamine (Fansidar). ${ }^{4}$ Nevertheless, $4^{\circ}{ }_{0}$ of the patients so treated developed a repeat attack during the early convalescent period, which was diagnosed as a recrudescence.

The US Army Malaria Research Programme has developed a new antimalarial drug-mefloquine hydrochloride (WR 142490 ; $\alpha$-(2-piperidyl), 8-bis (trifluoromethyl)-4-quinolinemethanol hydrochloride). ${ }^{5}$ We compared the effects of mefloquine and Fansidar, both given in single doses, in patients with falciparum malaria. ${ }^{6}$ Those who were severely ill or had an initial parasite concentration of over $200 \times 10^{9} / 1$ were excluded. Treatment with mefloquine alone failed early in the study in one patient whose initial parasite density was $171 \mathrm{x}$ $10^{9} / 1$. Therefore we compared sequential treatment with quinine-Fansidar and quinine-mefloquine in an unselected group of patients, which included some who were severely ill or had complications.

\section{Patients and methods}

Prachinburi Provincial Hospital (Chao Phya Abhai Bhu Bejhr Hospital) is in north-east Thailand $100 \mathrm{~km}$ from Bangkok. Malaria is endemic in many areas of the province. The study was performed in February to September 1975. Thai male volunteers aged over 15 years who lived in the endemic area were selected for the study. Unselected patients with falciparum malaria (including those with 